\title{
YOHANES DUNS SCOTUS DAN MARTIN HEIDEGGER TENTANG “ADA ITU UNIVOK"1
}

\author{
Hieronimus Yoseph Dei RupA*
}

\begin{abstract}
Abstrak: Tujuan dari artikel ini adalah menginterpretasi dan mengafirmasi bahwa Ada (das Sein) dalam "pertanyaan tentang Ada" (die Seinsfrage) dalam pemikiran Heidegger adalah univok sebagaimana konsep Ada itu univok dalam pemikiran Duns Scotus. Oleh karena itu, pertanyaan utama yang menuntun artikel ini adalah, bagaimana dapat ditunjukkan hubungan antara konsep Ada itu univok antara Dun Scotus dan Heidegger? Untuk memahami dengan baik tema ini, kita akan mengulasnya dalam empat bagian. Pertama, kita akan berkonsentrasi pada pengertian konsep ekuivok, analog, univok. Kedua, kita fokus pada konsep analogi dan univok dalam pemahaman Abad Pertengahan. Bagaimana Duns Scotus memahami Ada itu univok akan dijelaskan pada bagian ketiga. Kemudian, kita akan mengelaborasi sebuah penafsiran Ada itu univok dalam pemikiran Heidegger pada bagian keempat. Pada akhirnya, konsep Ada itu univok dalam pemikian Heidegger terletak pada konsepnya tentang waktu.
\end{abstract}

Kata-kata kunci: Ekuivok, analog, univok, metafisika, Ada, Dasein, Innerzeitigkeit, Zeitlichkeit, ekstasis, transendental.

Abstract: The scope of this article is to interpret and affirm that Being (das Sein) in Heidegger's "question of Being" (die Seinsfrage) is similarly univocal to Duns Scotus' concept of the univocity of Being. Therefore, the central question which guides this article is, how can it point to the relationship between Duns Scotus and Heidegger in

* Hieronimus Yoseph Dei Rupa, Program Studi Ilmu Filsafat, Sekolah Tinggi Filsafat Driyarkara, Jl. Cempaka Putih Indah 100A, Jembatan Serong, Rawasari, Jakarta 10520. Email: hieron.rupa@driyarkara.ac.id.

1 Tulisan ini berawal dari makalah yang telah disajikan dalam Kuliah Pembukaan Tahun Akademik 2017/2018, di Sekolah Tinggi Filsafat Driyarkara, Jakarta, pada 21 Agustus 2017. Makalah tersebut direvisi untuk kepentingan penerbitan artikel ini. 
regards to the concept of the univocity of Being? To understand well this theme, we will explain it in four parts. First, we concentrate on the definitions of equivocity, analogy and univocity. Second, we focus on the concepts of analogy and univocity in the Middle Ages. How Duns Scotus understands the univocity of Being will be pointed out in third part. After that, we will elaborate an interpretation of the univocity of Being in Heidegger's thought in fourth part. In the end, concept of the univocity of Being in Heidegger's thought is put in his concept of time.

Keywords: Equivocity, analogy and univocity, metaphysics, Being, Dasein, Innerzeitigkeit, Zeitlichkeit, ecstatic, transcendence.

\section{PENGANTAR}

Dalam magnum opus, Différence et repetition yang diterbitkan pertama kali pada tahun1968 dan diterjemahkan ke dalam bahasa Inggris, Difference and Repetition pada tahun 1994, filsuf perancis, Gilles Deleuze (19251995) menyatakan dengan keyakinan, "If it is true that some commentators have found Thomist echos in Husserl, Heidegger, by contrast, follows Duns Scotus and gives renewed splendour to the univocity of being."2 Baginya, jika beberapa komentator telah menemukan gema atau gaung pemikiran Tomas Aquinas dalam karya-karya Bapak Fenomenologi, Edmund Husserl (1859-1938), maka sebaliknya Martin Heidegger (1889-1976) mengikuti pemikiran dan memberikan pembaruan yang mengagumkan terhadap konsep Ada itu univok menurut Yohanes Duns Scotus (12661308). Pernyataan Deleuze menjadi salah satu alasan untuk mengkaji bagaimana Heidegger mengikuti dan memberikan sebuah "karakter baru" dalam konsep Ada, yaitu, Ada itu univok dalam filsafatnya.

Pertanyaan dan persoalan tentang Ada terkait dengan ilmu metafisika. Duns Scotus memahami, sebagaimana umumnya pada Abad Pertengahan, bahwa metafisika adalah ilmu yang berkaitan dengan yang transendental. ${ }^{3}$ Salah satu konsep transendental yang merupakan objek

2 Gilles Deleuze, Difference and Repetition, translated by P. Patton (New York: Columbia University Press, 1994), p. 66.

3 Dalam karyanya tentang metafisika, Duns Scotus menyatakan bahwa haruslah ada ilmu yang umum atau universal yang mempelajari yang transendental. Ilmu ini disebut "metafisika," dari "meta" yang berarti "melampaui," dan "ilmu fisika-alam." Me- 
dari metafisika, menurut Duns Scotus, adalah persoalan ada sebagai ada (being as being). ${ }^{4}$

Pertanyaan tentang Ada juga dielaborasi oleh Heidegger pada abad ke-20. "Apa arti dari Ada?" (die Frage nach dem Sinn von Sein) inilah pertanyaan utama yang menuntun, dalam satu dan lain cara, pemikiran Heidegger. Bagi Heidegger, filsafat sebelumnya telah melupakan pertanyaan mendasar yakni pertanyaan tentang Ada. Oleh karena itulah, perlu dimunculkan kembali pertanyaan tentang Ada untuk memahami lebih tepat artinya. ${ }^{5}$

Tulisan ini akan mengelaborasi konsep Ada itu univok dari dua filsuf, yakni, Yohanes Duns Scotus, seorang filsuf dan teolog Abad Pertengahan dan Martin Heidegger, seorang filsuf abad XX. Dengan ini juga akan ditunjukkan adanya kontinuitas antara filsafat Abad Pertengahan dan filsafat Kontemporer. Sebelum kita berkonsentrasi pada pemikiran kedua filsuf ini, kita perlu memahami arti dari ekuivok, analog dan univok yang berasal dari Aristoteles, lalu dikembangkan lebih lanjut oleh Tomas Aquinas (1225-1274) dan Duns Scotus. Kemudian kita akan mengelaborasi konsep Ada itu univok yang terkait erat dengan konsep waktu Dasein yang adalah univok

\section{MEMAHAMI ARTI KONSEP EKUIVOK, ANALOG DAN UNIVOK}

Aristoteles menjelaskan arti ekuivok dan univok dalam karyanya ${ }^{6}$ dan analogi dalam karyanya Ethica. ${ }^{7}$ Dalam karya logika ini khususnya

tafisika adalah ilmu yang "transenden" artinya ilmu yang berkonsentrasi pada yang transendental. John Duns Scotus, "Man's Natural Knowledge of God," in Duns Scotus Philosophical Writings, translated by A. Wolter and edited by R. Klibansky (Indianapolis: Hackett Publishing Company, 1987), p. 2.

4 Ioannis Duns Scoti,"Ordinatio, I, d. 3, p. 1, q. 1-2, n. 17," in Opera Omnia, vol. III (Civitas Vaticana: Typis Polyglottis Vaticanis, 1954), p. 9.

5 Martin Heidegger, Sein und Zeit, Gesamtausgabe Band 2 (Frankfurt am Main: Vittorio Klostermann, 1977), S. 3. Untuk selanjutnya karya pokok Martin Heidegger Sein und Zeit disingkat SZ), . Penulis menggunakan juga versi terjemahan dalam bahasa Inggris. Martin Heidegger, Being and Time, translated by J. Macquarrie \& E. Robinson (Malden: Blackwell Publishing, 1962), p. 21. Untuk selanjutnya terjemahan Being and Time disingkat $B T$.

6 Aristotle, "Categories," in The Complete Works of Aristotle, vol. I, translated by J.L. Ackrill and edited by J. Barnes (Princeton, N.J.: Princeton University Press, 1991), pp. 1-27. Dalam karya ini selain dijelaskan bagaimana kata "ada" yang digunakan sebagai substansi dan aksiden, kita menemukan pula penjelasannya tentang ekuivok dan univok.

7 Aristotle, "Nicomachean Ethics," in The Complete Works of Aristotle, vol. II, translated 
pada bab pertama, ia menunjukkan secara jelas pengertian-pengertian tersebut:

When things have only a name in common and the definition of being which corresponds to the name is different, they are called homonymous. Thus, for example, both a man and a picture are animals. These have only a name in common and the definition of being which corresponds to the name is different; for if one is to say what being an animal is for each of them, one will give two distinct definitions. When things have the name in common and the definition of being, which corresponds to the name is the same, they are called synonymous. Thus, for example, both a man and an ox are animals. Each of these is called, by a common name, an animal, and the definition of being is also the same; for if one is to give the definition of each - what being an animal is for each of them-one will give the same definition. When things get their name from something, with a difference of ending, they are called paronymous. Thus, for example, the grammarian gets his name from grammar, the brave get theirs from bravery. ${ }^{8}$

Aristoteles mendefinisikan bahwa sesuatu dikatakan homonim jika mereka mempunyai sebuah nama yang sama, namun definisi atau pengertiannya berbeda untuk masing-masing. ${ }^{9}$ Rumusannya adalah sebagai berikut: $x$ dan $y$ adalah $F$ yang homonim, jika dan hanya jika: (i) $x$ adalah F; (ii) y adalah F; dan (iii) pengertian $F$ dalam ' $x$ adalah $F$ ' and 'y adalah F' sama sekali tidak sama. Contoh yang diberikan Aristoteles adalah sebagai berikut: "seorang manusia" (x) dan "seorang figur di dalam sebuah gambar" (y) adalah homonim binatang (F), jika dan hanya jika: (i) "seorang manusia" (x) adalah binatang $(\mathrm{F})$; (ii) "seorang figur di dalam sebuah gambar" (y) adalah binatang $(\mathrm{F})$; dan (iii) pengertian binatang $(\mathrm{F})$ dalam keduanya sama sekali tidak sama atau berbeda, satunya merujuk

by W. D. Ross and edited by J. Barnes (Princeton, N.J.: Princeton University Press, 1991). Dalam 10 buku karya utama etika ini, Aristoteles menjelaskan antara lain beberapa tema penting seperti kebahagiaan sebagai keutamaan tertinggi, keutamaan dan bahaya dari ketidakmampuan mengendalikan diri. Dalam buku pertama, kita menemukan arti analogi Aristoteles dalam penjelasannya tentang kebaikan (good).

8 Aristotle, Categories, 1a1-15, p. 2.

9 Secara etimologis, kata ekuivok berasal dari bahasa latin, aequivocus, yang berarti, bunyi yang sama atau identik dan dari kata equi-, aequus yang berarti sama dan kata vōx yang berarti suara. Vocare berarti memanggil. Jadi ekuivok berarti bunyi atau suara yang sama atau identik, namun berbeda dalam definisinya. Lih. "Online Etymology Dictionary," http://www.etymonline.com/index.php?allowed_in_frame=0\&search=equivocal (diakses hari Kamis, 17 Agustus 2017). 
pada "seorang manusia yang real, bertubuh" dan yang lain merujuk pada "sebuah gambar figur tertentu."

Homonim ini dibagi dalam dua bagian. ${ }^{10}$ Pertama, homonim yang berbeda (discrete homonymy). Sesuatu adalah homonim yang berbeda, jika dan hanya jika, mereka mempunyai nama yang sama, tetapi definisi atau pengertian mereka berbeda dan tidak saling berhubungan atau tidak saling berkaitan sama sekali. Ia menunjukkan sesuatu yang berbeda di bawah nama yang sama. Pernyataan "bisa ular" dan "kita bisa" menunjukkan yang pertama berarti "racun" dan yang terakhir berarti "dapat" berada di bawah kata yang sama "bisa." Pengertian keduanya berbeda kendati nama mereka sama dan keduanya tidak berkaitan sama sekali. Homonim yang berbeda ini disebut juga ekuivok.

Kedua, homonim yang berkaitan (comprehensive homonymy). Sesuatu adalah homonim yang berkaitan atau berhubungan, jika dan hanya jika, mereka mempunyai nama yang sama dan pengertian atau definisi mereka tidak berhubungan secara sempurna namun ada hubungan atau keterkaitan diantara mereka, yakni, keterarahan kepada sesuatu (relative homonymy). Kata "sehat" misalnya digunakan pada pernyataan "orang yang sehat," "kulit yang sehat," "makanan yang sehat." Semuanya (orang, kulit, makanan) terkait atau terhubung dan terarah kepada kata "sehat." Kata "sehat" adalah titik sentral yang menghubungkan sesuatu yang melekat padanya seperti orang, kulit dan makanan. Demikianlah menurut Aristoteles dalam Metafisika bahwa ada banyak pengertian tentang ada, namun mereka terhubung atau terkait kepada satu titik sentral, kepada satu ada yang pasti. ${ }^{11}$ Pada Abad Pertengahan, misalnya Tomas Aquinas, akan menyebut homonim yang berkaitan (comprehensive homonymy) atau keterarahan kepada sesuatu (relative homonymy) sebagai analogi.

Sinonim atau univok berarti sesuatu yang mempunyai nama dan definisi atau pengertiannya yang sama. ${ }^{12}$ Rumusannya adalah bahwa: $x$ dan

10 Lih. C. Shields, Order in Multiplicity, Homonymy in the Philosophy of Aristotle (Oxford: Oxford University Press, 1999), p. 1.

11 Aristotle, "Metaphysics, Г 2, 1003a33-b.10," in The Complete Works of Aristotle, vol. II, translated by W. D. Ross and edited by J. Barnes (Princeton, N.J.: Princeton University Press, 1991), p. 42.

12 Secara etimologis, kata univok berasal dari bahasa latin univocus, dari kata unus artinya 
y adalah F yang univok, jika dan hanya jika: (i) keduanya adalah $\mathrm{F}$ dan (ii) definisi-definisi berhubungan dengan $F$ di dalam " $x$ adalah $F$ " dan " $y$ adalah F" adalah sama. Contoh yang diberikan oleh Aristoteles sebagai berikut: "seorang manusia" dan "seekor lembu jantan" adalah binatang, maka nama dan definisi binatang keduanya sama, keduanya real, bertubuh. Univok disebut juga dengan nama sinonim.

Konsep analogi ${ }^{13}$ - salah satunya - dijelaskan pada buku pertama Ethica Nicomachea ketika ia berbicara tentang kebaikan. Sebenarnya, Aristoteles membicarakan tema tentang analogi, istilah $\dot{\alpha} v \alpha \lambda o \gamma i \alpha$ and

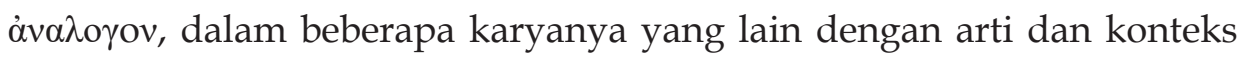
yang berbeda. Dalam Analytica Priora, analogi dipertimbangkan sebagai sebuah cara rasionalisasi atau sebuah cara berpikir:

"We must consider too the other kinds of objection, namely the objection from contraries, from similars, and from common opinion, and inquire whether a particular objection cannot be elicited from the first figure or a negative objection from the second;"14 dalam, Poetica, "Metaphor consists in giving the thing a name that belongs to something else; the transference being either from genus to species, or from species to genus, or from species to species, or on grounds of analogy"15 dan, Rhetorica, "The simile also is a metaphor; the difference is but slight. When the poet says: He leapt on the foe as a lion, this is a simile"16 dan "Successful similes also, as has been said above, are in a sense metaphors, since they always involve two relations like the proportional

satu dan kata vox artinya suara, kata, bunyi. Univok artinya satu suara, satu bunyi, satu kata dan mempunyai hanya satu arti. Lih. "Online Etymology Dictionary," http:/ / www.etymonline.com/index.php?allowed_in_frame=0\&search=univok (diakses hari Kamis, 17 Agustus 2017).

13 Analogi berasal dari bahasa latin, analogia dan dari bahasa Yunani, analogia yang berarti perbandingan "proportion," dari kata ana- artinya menurut dan logos artinya rasio, proporsi, perbandingan, kata. Analogi berarti menurut proporsi, perbandingan. Lih. "Online Etymology Dictionary," http://www.etymonline.com/index.php?allowed_ in_frame=0\&search=analogy (diakses hari Kamis, 17 Agustus 2017).

14 Aristotle, "Prior Analytics, II, 26, 69b38-70a2," in The Complete Works of Aristotle, vol. I, translated by A. J. Jenkinson and edited by J. Barnes (Princeton, N.J.: Princeton University Press, 1991), p. 88.

15 Aristotle, "Poetics, 21, 1457b 7-10," in The Complete Works of Aristotle, vol. II, translated by I. Bywater and edited by J. Barnes (Princeton, N.J.: Princeton University Press, 1991), pp. 21 - 22.

16 Aristotle, "Rhetoric, III, 4, 1046b 20-23," in The Complete Works of Aristotle, vol. II, translated by W. Rhys Roberts and edited by J. Barnes (Princeton, N.J.: Princeton University Press, 1991), p. 112. 
metaphor,"17

analogi dipahami dan diaplikasikan sebagai metaphor; dalam, Metaphysica analogi dilihat sebagai kategori dari ada, "We must observe that no one could find difficulty either in stating such analogies or in finding them in eternal things, since they can be found even in perishable things,"18 dalam analogi dipahami dan diaplikasikan dalam fisika dan ilmu khususnya ketika Aristoteles menjelaskan tentang gerakan.

Dalam Ethica Nicomachea, analogi dipertimbangkan sebagai sebuah perbandingan atau relasi ilmu hitung (arithmetic): The good, therefore, is not something common answering to one Idea. But then in what way are things called good? They do not seem to be like the things that only chance to have the same name (homonymy). Are goods one, then, by being derived from one good or by all contributing to one good, or are they rather one by nalogy? Certainly as sight is in the body, so is reason in the soul, and so on in other cases. ${ }^{19}$

Dalam kutipan ini, Aristoteles mempertanyakan apakah kebaikankebaikan adalah satu dengan berasal dari satu kebaikan atau semua kebaikan berkontribusi kepada satu kebaikan atau mereka adalah satu melalui analogi. Analogi dipahami seperti penglihatan yang ada di dalam tubuh, sama seperti intelek yang ada di dalam jiwa dan sebagainya. Analogi berarti bahwa kebaikan-kebaikan yang berbeda tidak mempunyai penyebab yang sama atau akhir yang sama, tetapi mereka mempunyai sebuah sifat sepadan atau sebanding dalam relasi diantara mereka, diantara kebaikan-kebaikan tersebut, sebagaimana hubungan antara penglihatan di dalam tubuh serta intelek di dalam jiwa. Analogi Aristoteles ini disebut analogi sebanding atau sepadan (analogy of proportionality) karena ada relasi kemiripan (similarity) dan perbandingan (comparison) antara dua bagian atau nama yang berbeda. Relasi ini dapat dirumuskan sebagai berikut: $\mathrm{a} / \mathrm{b}=\mathrm{c} / \mathrm{d}=\mathrm{e} / \mathrm{f}=\mathrm{g} / \mathrm{h} .{ }^{20}$

17 Aristotle, Rhetoric, III, 11, 1412b 33-34, p. 126.

18 Aristotle, Metaphysics, N 6, 1093b 17-19, p. 216.

19 Aristotle, Nicomachean Ethics, I, 6, 1096b 26-30, p. 7.

20 E. Berti, "L'analogia dell'essere nella tradizione aristotelico-tomistica," in Metafore dell'invisibile: ricerche sull'analogia, contribute al XXXIII Convegno del Centro di Studi filosofici di Gallarate - Aprile 1983 (Brescia: editrice Morcelliana, 1984), pp. 15-16. 


\section{ANALOGI DAN UNIVOK PADA ABAD PERTENGAHAN}

Pada Abad Pertengahan, Aquinas dan Duns Scotus mengembangkan pengertian dan pemahaman Aristoteles berkaitan dengan konsep ekuivok, analog dan univok. Ketiga konsep ini digunakan dalam perdebatan filsafat dan teologi Abad Pertengahan berkaitan dengan pengetahuan akan Allah. Sebagaimana diketahui bahwa, salah satu ciri filsafat dan teologi Abad Pertengahan adalah bagaimana manusia dapat mengetahui Allah atau pengetahuan tentang Allah. ${ }^{21}$ Bagi pemikir Abad Pertengahan, menunjukkan bahwa kita dapat mengetahui Allah sama pentingnya dengan membuktikan bahwa Allah ada. ${ }^{22}$

Berhadapan dengan pertanyaan tersebut, Aquinas mengatakan bahwa pengetahuan atau nama Allah hanya diketahui secara analogi, bukan secara univok dan ekuivok. Baginya, univok yang berarti nama dan pengertian sama secara sempurna dan ekuivok yang berarti nama sama dan pengertian yang sangat berbeda, tidak tepat diberlakukan kepada nama atau pengetahuan akan Allah. Sebaliknya yang paling tepat dan benar dalam pengetahuan akan Allah dan nama Allah adalah analogi.

I answer that, this name God in the three aforesaid significations is taken neither univocally nor equivocally, but analogically. This is apparent from this reason: Univocal terms mean absolutely the same thing, but equivocal terms absolutely different; whereas in analogical terms a word taken in one signification must be placed in the definition of the same word taken in other senses; as, for instance, being which is applied to substance is placed in the definition of being as applied to accident; and healthy applied to animal is placed in the definition of healthy as applied to urine and medicine. For urine is the sign of health in the animal, and medicine is the cause of health. ${ }^{23}$

21 J. Gracia, "Philosophy in the Middle Ages: An Introduction," in A Companion to Philosophy in the Middle Ages, edited by J. Gracia and T. B. Noonep (Malden: Blackwell Publishing, 2006), pp. 1-11. Secara umum kita dapat mengamati ada tujuh tema yang didiskusikan pada Abad Pertengahan: 1) relasi antara iman dan akal budi; 2) eksistensi Allah; 3) nama-nama, atribut-atribut atau pengetahuan akan Allah; 4) teologi dan metafisika; 5) bagaimana kita mengetahui; 6) universal, dan; 7) individuasi.

22 J. Gracia, Philosophy in the Middle Ages: An Introduction, p. 6.

23 "Respondeo dicendum quod hoc nomen Deus, in praemissis tribus significationibus, non accipitur neque univoce neque aequivoce, sed analogice. Quod ex hoc patet. Quia univocorum est omnino eadem ratio: aequivocorum est omnino ratio diversa: in analogicis vero, oportet quod 
Aquinas mengakui dan menerima konsep analogi Aristoteles yang berciri sebanding atau sepadan (analogy of proportionality). ${ }^{24}$ Namun demikian, dalam konteks pengetahuan atau nama Allah, Aquinas memberi penekanan pada analogi yang memiliki keterkaitan, hubungan dan keterarahan kepada satu titik sentral tertentu, yakni, Allah sendiri. Ia menolak konsep univok dan ekuivok dalam memahami atribut atau nama Allah. Baginya, hanya analogi, tepatnya analogi yang berkaitan atau berhubungan (analogy of attribution) yang mampu untuk menjawab bagaimana manusia dapat mengetahui Allah atau pengetahuan tentang Allah. Karakter dari analogi Aquinas ini adalah adanya pertalian dan keterkaitan antara analog-analog atau bagian-bagian yang dibandingkan. Analogi ini memiliki nama yang sama tetapi artinya berbeda dan relasinya terarah kepada satu titik sentral tertentu. Rumusan relasi ini adalah a/a, b/a, c/a, d/a... di mana a, b, c dan d memiliki pengertian yang berbeda meski mereka memiliki nama yang sama, yakni, a.

Berhadapan dengan pertanyaan apakah manusia dapat mengetahui Allah atau dapatkah nama-nama atau atribut-atribut yang kita gunakan dalam dunia kita (seperti ada, baik, bijak dan adil) diterapkan atau digunakan kepada Allah, Aquinas menunjukkan bahwa kita dapat mengetahui dan menerapkan nama-nama dan istilah-istilah yang kita

nomen secundum unam significationem acceptum, ponatur in definitione eiusdem nominis secundum alias significationes accepti. Sicut ens de substantia dictum, ponitur in definitione entis secundum quod de accidente dicitur; et sanum dictum de animali, ponitur in definitione sani secundum quod dicitur de urine et de medicina; huius enim sani quod est in animali, urina est significativa, et medicina factiva." Thomae de Aquino, "Summae Theologie, p.1, q.13, art.10," vol. IV, in Opera Omnia, (Romae: editio Leonina, 1888), p. 160. Penulis juga menggunakan terjemahan dalam bahasa Inggris dari para Imam Dominikan Provinsi Inggris. Thomas Aquinas, "Summa Theologica, p. 1, q. 13, art. 10, obj. 3," vol. I, in Complete English Edition in Five Volumes, translated by Fathers of the English Dominican Province (Notre Dame, Indiana: Ave Maria Press, 1948) p. 69.

24 Para komentator Tomas Aquinas pada umumnya sepakat bahwa ada dua konsep analogi dalam pemikiran Aquinas. Pertama, analogi yang sebanding atau sepadan (analogy of proportionality or analogy of proportion). Kedua, analogi yang berkaitan atau berhubungan (analogy of attribution). Bdk. E. Berti, L'analogia dell'essere nella tradizione aristotelico-tomistica, pp. 13-33; Bdk. E. Berti, "L'analogia in Aristotele interpretazioni recenti e possibili sviluppi," in Origini e sviluppi dell'analogia: da Parmenide a San Tommaso, a cura di G. Casetta, (Roma: Edizioni Vallombrosa, 1987), pp. 94-115; Bdk. B. Montagnes, The Doctrine of the Analogy of Being According to Thomas Aquinas, translated by E. M. Macierowski and edited by A. Tallon (Milwaukee: Marquette University Press, 2004), p. 16. 

gunakan kepada Allah secara analogi (dalam arti analogy of attribuation). "Allah adalah baik" berarti kebaikan Allah adalah sempurna dan abadi sedangkan "Joko adalah baik" berarti kebaikan Joko tidaklah sempurna dan tidak abadi seperti Allah. Ada kesamaan namun sekaligus perbedaan antara kebaikan Allah dan kebaikan Joko. Dalam hal ini, kebaikan Joko yang tidak sempurna terarah dan berpartisipasi kepada kebaikan Allah yang sempurna. Hubungan keterarahan dan partisipasi yang bersifat hierarki ini dimaknai sebagai pengakuan terhadap Allah sebagai pencipta manusia, Joko. Jadi kebaikan Joko berasal dari Allah dan terarah kepada Allah sendiri.

Tidak dapat dimungkiri bahwa pemikiran Aquinas tentang analogi yang berhubungan atau berkaitan merupakan langkah lanjut pengembangan dari konsep homonim yang berkaitan (comprehensive homonymy) dari Aristoteles yang telah disebutkan sebelumnya. Jika Aristoteles tidak menyebut konsep homonim yang berkaitan sebagai analogi, maka pada Abad Pertengahan umumnya - dan sangat dipengaruhi oleh Aquinas konsep itu disebut dengan analogi. Hanya analogi inilah - analogi yang berhubungan dan terarah kepada satu titik sentral - menurut Aquinas, yang mampu menjawab pengetahuan kita akan Allah.

\section{YOHANES DUNS SCOTUS: KONSEP ADA ITU UNIVOK}

Duns Scotus, sebagai anak zaman, juga menggeluti pertanyaan yang sama dengan Aquinas. Berbeda dengan jawaban Aquinas yang menekankan analogi, tepatnya, analogi yang berkaitan dan terarah pada satu titik sentral, Duns Scotus menyatakan teorinya bahwa hanya sebuah konsep ada yang univok (a univocal concept of being) yang mampu dan diperlukan untuk mengetahui Allah. Intelek manusia dalam keterbatasan ruang dan waktu (baca: dunia) dapat memahami Allah secara univok.

Dalam Ordinatio, pada tema kemungkinan mengetahui Allah, yaitu, apakah intelek manusia dalam keterbatasan ruang dan waktu mampu mengetahui Allah secara alamiah, Duns Scotus menyatakan: "I say that God is conceived not only in a concept analogous to the concept of a creature, 
that is, one which is wholly other than that which is predicated of creature, but even in some cencept univocal to Himself and to a creature." 25 Tampak bagi Duns Scotus, Allah dapat dipahami dalam konsep umum yang univok bagi diri-Nya sendiri dan bagi ciptaan-ciptaan-Nya. Pengetahuan akan Allah tidak hanya dipahami dalam konsep analogi tetapi juga, lebih tepat, dalam konsep univok. Ini berarti bahwa ia tidak menolak konsep analogi dalam pengetahuan akan Allah sebagaimana dijelaskan oleh Aquinas tetapi baginya analogi itu akan mungkin digunakan, jika didasarkan pada konsep univok. Konsep analogi mensyaratkan adanya konsep univok.

Setelah menunjukkan keyakinannya bahwa konsep univok adalah jawaban yang tepat untuk mengetahui Allah, Duns Scotus merumuskan lebih lanjut arti dari univok yang dimaksudkannya:

And lest there be a dispute about the name "univocation," I designate that concept univocal which possesses sufficient unity in itself, so that to affirm and deny it of one and the same thing would be a contradiction. It also has sufficient unity to serve as the middle term of a syllogism, so that wherever two extremes are united by a middle term that is one in this way, we may conclude to the union of the two extremes among themselves. ${ }^{26}$

Univok yang dimaksudkan adalah konsep yang memiliki kesatuan yang cukup dalam dirinya sendiri sehingga mampu mengafirmasi dan menolak konsep dari sesuatu yang satu dan sama yang tampak sebagai sebuah kontradiksi. Konsep univok ini pula memiliki kesatuan yang cukup sebagai sebuah middle term dari dua konsep ekstrem sehingga kita dapat menyimpulkan kesatuan diantara kedua konsep yang berbeda. ${ }^{27}$

25 "Dico quod non tantum in conceptu analogo conceptui creaturae concipitur Deus, scilicet qui omnino sit alius ab illo qui de creatura dicitur, sed in conceptu aliquo univoco sibi et creaturae." Ioannis Duns Scoti, Ordinatio, I, d. 3, p. 1, q. 1-2, n. 26, p. 18; Lih. John Duns Scotus, Man's Natural Knowledge of God, p. 19.

26 "Et ne fiat contentio de nomine univocationis, univocum conceptum dico, qui ita est unus quod eius unitas sufficit ad contradictionem, affirmando et negando ipsum de eodem; sufficit etiam pro medio syllogistico, ut extrema unita in medio sic uno sine fallacia aequivocationis concludantur inter se uniri." Ioannis Duns Scoti, Ordinatio, I, d. 3, p. 1, q. 1-2, n. 26, III, p. 18; Lih. John Duns Scotus, Man's Natural Knowledge of God, p. 19. Penekanan dari penulis.

27 "Et ne fiat contentio de nomine univocationis, univocum conceptum dico, qui ita est unus quod eius unitas sufficit ad contradictionem, affirmando et negando ipsum de eodem; sufficit etiam pro medio syllogistico, ut extrema unita in medio sic uno sine fallacia aequivocationis concludantur inter se uniri." Ioannis Duns Scoti, Ordinatio, I, d. 3, p. 1, q. 1-2, n. 26, III, p. 18; Lih. John Duns Scotus, Man's Natural Knowledge of God, p. 20. 

Allah adalah sempurna dan abadi sedangkan "Joko adalah baik" berarti kebaikan Joko juga sempurna dan abadi seperti Allah. Ada persamaan antara kebaikan Allah dan kebaikan Joko. Oleh karena itu, kebaikan memiliki arti yang satu dan sama kepada Allah dan Joko. ${ }^{28}$ Tentu saja, ini menimbulkan kebingungan bagi orang beriman karena tampak bahwa Allah dan Joko sama dan sempurna kebaikan mereka. Dampak paling jauh, pencipta dan ciptaan menjadi sama.

Duns Scotus tentu saja memahami dengan baik kebingungan dan keresahan orang-orang beriman. Ia tidak bermaksud menunjukkan bahwa Allah-pencipta dan Joko-ciptaan adalah sama dan satu tanpa perbedaan di antara mereka. Sebaliknya, bagi Duns Scotus perbedaan mereka terletak pada cara atau model kebaikan atau ada, yakni, bahwa kebaikan Joko terbatas karena ia ciptaan yang ada dalam ruang dan waktu (baca: dunia) sedangkan kebaikan Allah tidak terbatas dan sempurna karena Dia adalah pencipta, tanpa ruang dan waktu.

Berkaitan dengan konsep ada, bagi Duns Scotus, berlaku demikian pula. Bahwa konsep ada seperti middle term yang menyatukan dua konsep yang berbeda. Baginya, konsep ada datang lebih dahulu dari konsep ada yang tidak terbatas-pencipta dan ada yang terbatas-ciptaan. Konsep ada mempersatukan keduanya, yang tidak terbatas dan yang terbatas. Jadi tidak ada hubungan keter-arahan dan partisipasi yang bersifat hierarkis. Ciri yang menonjol dalam konsep univok adalah kesatuan konsep. ${ }^{29}$

Ada empat argumen yang diberikan oleh Duns Scotus untuk mempertahankan teori konsep ada itu univok. Pertama, kita dapat yakin terhadap satu konsep sementara meragukan konsep yang lain. Dalam kehidupan sehari-hari, seorang pribadi dapat yakin dalam pikirannya bahwa Allah adalah seorang atau sebuah ada dan masih ragu-ragu apakah

28 "Deus concipitur in conceptu communi univoco sibi et creaturae." Ioannis Duns Scoti, Lectura, 1, d. 3, p. 1, q. 1-2, n. 21, XVI, p. 232.

29 "De secundo articulo est dicendum, in quo expresse sibi contradico, quod non concipitur Deus in conceptu communi analogo sibi et creaturae, sed in conceptu communi univoco sibi et creaturae, ita quod ens et bonum et sapientia dicta de Deo et creatura univoce dicuntur de eis, et non dicunt duos conceptus." Ioannis Duns Scoti, Lectura, I, d. 3, p. 1, q. 1-2, n. 21, XVI, p. 232. 
Dia adalah ada yang tidak terbatas atau terbatas, ada yang diciptakan atau tidak diciptakan. Ini menunjukkan secara jelas bahwa penger-tian konsep ada yang diterapkan kepada Allah (baca: Allah adalah sebuah ada) berbeda dari dua konsep yang lain (baca: tidak terbatas dan terbatas). Akan tetapi konsep ada merangkum keduanya, Allah - tidak terbatas dan terbatas. Oleh karena itu univok. ${ }^{30}$

Kedua, dalam sejarah filsafat setiap filsuf menunjukkan bahwa prinsip pertama baginya adalah sebuah ada. Seseorang bisa mengatakan api adalah sebuah ada, yang lain mengatakan air adalah sebuah ada. Namun ia tidak yakin apakah ada itu adalah sebuah ada yang diciptakan atau sebuah ada yang tidak diciptakan, yang pertama atau bukan yang pertama. ${ }^{31}$

Ketiga, tidak ada pengetahuan tentang Allah atau realitas yang ilahi tanpa konsep univok antara Allah atau realitas yang ilahi dan ciptaan. Dengan kata lain, mengingkari konsep univok berarti meyakini bahwa pengetahuan manusia tentang Allah tidak mungkin. ${ }^{32}$ Duns Scotus berargumen bahwa dalam kondisi kita di dunia, terbatas pada ruang dan waktu, semua pengetahuan kita berasal dari persepsi indera kita. Ini hanya membawa dan membentuk konsep-konsep yang sederhana yang sesuai dengan apa yang kita persepsi. Tidak ada dasar untuk membentuk

30 "Primo sic: omnis intellectus, certus de uno conceptu et dubius de diversis, habet conceptum de quo est certus alium a conceptibus de quibus est dubius; subiectum includit praedicatum. Sed intellectus viatoris potest esse certus de Deo quod sit ens, dubitando de ente finite vel infinito, creato vel increato; ergo conceptus entis de Deo est alius a conceptu isto et illo, et ita neuter ex se et in utroque illorum includitur; igitur univocus." Ioannis Duns Scoti, Ordinatio, I, d. 3, p. 1, q. 1-2, n. 27, III, p. 18; Lih. John Duns Scotus, Man's Natural Knowledge of God, p. 20.

31 "Quilibet philosophus fuit certus, illud quod posuit primum principium, esse ens, - puta unus de igne et alius de acqua, certus erat quod erat ens; non autem fuit certus quod esset ens creatum vel increatum, primum vel non primum. Non enim erat certus quod erat primum, quia tunc fuisset certus de falso, et falsum non est scibile." Ioannis Duns Scoti, Ordinatio, I, d. 3, p. 1, q. 1-2, n. 29, III, pp. 18-19; Lih. John Duns Scotus, Man's Natural Knowledge of God, p. 20; Bdk. Ioannis Duns Scoti, Ordinatio. I, d. 3, p. 1, q. 1-2, n. 17, III, p. 9. "Secundo nota quod subiectum primae scientiae simul praecognoscitur: 'quid' dicitur per nomen et 'si est' et 'quid est'. Quia nulla scientia de suo subiecto primo quaerit 'si est' vel 'quid est,' ergo vel omnino non est quaeribile, vel tantum in scientia priore; prima nulla est prior; ergo de eius primo subiecto nullo modo est quaeribile 'si est' vel 'quid est.' Ergo conceptus simpliciter simplex, ergo ens."

32 S. Dumont, "Henry of Ghent and Duns Scotus," in Routledge History of Philosophy, vol. III, edited by J. Marenbon (London: Routlegde, 1998), p. 310. 
konsep-konsep analog yang sederhana. Maka perlu ada konsep umum yang sederhana dan memiliki pengertian yang sama antara pencipta dan ciptaan sehingga kita dapat mengetahui pencipta, Allah. Konsep itu adalah konsep ada. ${ }^{33}$

Keempat, setiap pencarian dan pertanyaan tentang Allah dalam metafisika berproses dengan abstraksi tentang kesempurnaan-kesempurnaan dari keterbatasan-keterbatasan dalam ciptaan dan mengatributkannya kepada Allah. Proses ini mensyaratkan adanya konsepyang univok antara Allah dan ciptaan. ${ }^{34}$ Konsep itu adalah ada. Konsep ada itu univok ditetapkan dalam metafisikanya dengan mempertimbangkan bahwa objek dari intelek dan metafisika adalah satu dan sama, yakni, ada. Jadi kita dapat memahami semua hal karena kita memiliki konsep yang original dan inheren yakni, ada. ${ }^{35}$

\section{MARTIN HEIDEGGER: ADA ITU UNIVOK}

Konsep "ada itu univok" dapat dicermati pada konsep waktu dalam pemikiran Heidegger. Kita akan membatasi pembahasan kita pada adanya konsep "ada itu univok" dalam karya Heidegger, Sein und Zeit yang ditulis sekitar tahun 1920-an dan diterbitkan tahun 1927.

Pada awal karya ini, Heidegger mengakui bahwa pertanyaan tentang ada (die Frage nach dem Sein) telah dilupakan. Kita tidak mempunyai jawaban terhadap pertanyaan ini. Kita menjadi bingung tentang pertanyaan dan arti dari kata ada (being-seiend). Karena alasan itulah, kita ha-

33 P. King, "Scotus on Metaphysics," in The Cambridge Companion to Duns Scotus, edited by T. Williams, (Cambridge: Cambridge University Press, 2003), p. 18.

34 S. Dumont, The Univocity of the Concept of Being in the Fourteenth Century: John Duns Scotus and William of Alnwick, in Mediaeval Studies 49 (1) (Toronto: Pontifical Institute of Mediaeval Studies, 1987), p. 26.

35 "Omnis inquisitio metaphysica de Deo sic procedit, considerando formalem rationem alicuius et auferendo ab illa ratione formali imperfectionem quam habet in creaturis, et reservando illam rationem formalem et attribuendo sibi omnino summam perfectionem, et sic attribuendo illud Deo. Exemplum de formali ratione sapientiae (vel intellectus) vel voluntatis: consideratur enim in se et secundum se; et ex hoc quod ista ratio non concludit formaliter imperfectionem aliquam nec limitationem, removentur ab ipsa imperfectiones quae concomitantur eam in creaturis, et reservata eadem ratione sapientiae et voluntatis attribuuntur ista Deo perfectissime. Ergo omnis inquisitio de Deo supponit intellectum habere conceptum eundem, univocum, quem accepit ex creaturis." Ioannis Duns Scoti, Ordinatio, I, d. 3, p. 1, q. 1-2 n. 39, III, pp. 26-27; John Duns Scotus, Man's Natural Knowledge of God, p. 25. 
rus memunculkan kembali pertanyaan tentang arti dari Ada (die Frage nach dem Sinn von Sein) dan mempertimbangkan lagi sebuah pemahaman yang tepat terhadap arti dari pertanyaan tentang Ada. Demikianlah Heidegger mengelaborasi pertanyaan tentang arti dari Ada dan pertanyaan ini adalah pertanyaan yang menuntun karyanya Sein und Zeit (Being and Time) ${ }^{36}$

Sedari awal pembahasan tentang Ada dalam SZ, Heidegger menunjukkan bahwa pertanyaan tentang arti dari Ada sangat terkait erat dengan waktu. "Pertanyaan tentang arti dari Ada harus memampukan kita untuk menunjukkan bahwa persoalan sentral dari semua ontologi berakar dalam fenomena waktu, jika dilihat secara benar dan dijelaskan secara tepat."37 Dalam pengertian inilah kita dapat memahami bahwa tema sentral dari SZ adalah menunjukkan bahwa, Dasein, ada (to be) selalu "mewaktu" karena waktu merupakan arti primordial dari Ada Dasein. ${ }^{38}$ Tepatlah jika Heidegger mengatakan sedari awal pada SZ bahwa perlulah memahami dengan baik interpretasi tentang waktu sebagai horizon yang mungkin untuk pemahaman tentang Ada. ${ }^{39}$ Jelaslah bagi Heidegger bahwa kunci untuk memahami Ada adalah waktu. Ada itu sendiri harus dipikirkan dalam waktu dan waktu adalah arti Ada Dasein. Keduanya saling terkait dan saling memiliki. ${ }^{40}$

Heidegger menunjukkan ada tiga konsep waktu. Mereka adalah waktu dari Ada (Temporalität des Seins), waktu dari mengada (Innerzeitigkeit) dan waktu dari Dasein (Zeitlichkeit). ${ }^{41}$ Namun demikian, dalam $S Z$ Heidegger lebih banyak menjelaskan tentang perbedaan antara dua

36 Heidegger, SZ, S. 1; BT, p. 19.

37 "Demgegenüber ist auf dem Boden der ausgearbeiteten Frage nach dem Sinn von Sein zu zeigen, daß und wie im rechtgesehenen und rechtexplizierten Phänomen der Zeit die zentrale Problematik aller Ontologie verwurzelt ist". Heidegger, SZ, S. 25.

38 Bdk. M. Watts, The Philosophy of Heidegger (Durham: Acumen Publishing Limited, 2011), p. 116.

39 "Die interpretation der Zeit als des möglichen Horizontes eines jeden Seinsverständnisses überhaupt ist ihr vorläufiges Ziel." Heidegger, SZ, S.1

40 Bdk. P. Gorner, Heidegger's Being And Time: An Introduction (Cambridge: Cambridge Unversity Press, 2007), p. 14.

41 Mengikuti catatan yang diberikan F. Budi Hardiman, Sein diterjemahkan dengan "Ada" dan Seiendes diterjemahkan dengan "mengada." F. Budi Hardiman, Heidegger dan Mistik Keseharian: Suatu Pengantar Menuju Sein und Zeit (Jakarta: Kepustakaan Populer Gramedia, 2003), hlm. 44-45. 
konsep waktu, yakni, waktu dari mengada (Innerzeitigkeit), sebagai waktu yang tidak otentik dan waktu dari Dasein (Zeitlichkeit), sebagai waktu yang otentik. ${ }^{42}$

Pertama, waktu dari Ada, temporalitas (Temporalität des Seins). Tipe waktu ini hanya diterapkan kepada Ada. Ia tidak dapat diterapkan pada Dasein dan mengada lainnya. Pertanyaan tentang Ada juga berarti pertanyaan tentang waktu dari Ada. Ini berarti bahwa upaya mencari pemahaman tentang arti dari Ada mencakup upaya memahami waktu dari Ada, temporalitas. ${ }^{43}$ Upaya ini akan terlaksana dengan tepat sasar jika kita mampu memahami waktu dari Dasein, sebagai mengada yang memiliki akses dan relasi dengan Ada. ${ }^{44}$

Kedua, waktu dari mengada (Innerzeitigkeit). Kata ini merupakan pembedaan dari in der Zeit (di dalam waktu) sehingga Innerzeitigkeit dapat dipahami sebagai "ke-ada-di-dalam-waktu-an." ${ }^{45}$ Innerzeitigkeit dipahami sebagai sekuensi atau proses pergantian titik-titik waktu yang muncul satu setelah yang lain. Titik waktu ini adalah "waktu-sekarang" (Jetzt-Zeit). ${ }^{46}$ Ada titik (baca: waktu sekarang) yang sudah lewat dan kita menyebutnya masa lalu; titik tempat kita berada disebut masa kini, dan; titik yang belum datang kita menyebutnya masa depan. Kita ada "di dalam" waktu berarti kita ada "'di dalam" kronologis titik-titik waktu itu. Innerzeitigkeit seperti sebuah garis lurus dengan titik-titik waktu yang sudah, sekarang dan akan kita lewati. Jadi "di dalam waktu” berarti "di dalam waktu-dunia" dan "waktu objektif sehari-hari." Konsep waktu yang vulgar ini (vulgaeres Zeitverständnis) terwujud dalam penggunaan jam, kalender atau sebuah kesepakatan bersama, misalnya, tanggal 1 Januari dirayakan sebagai tahun baru. Bagi Heidegger, Innerzeitigkeit

42 Tema temporalitas, waktu dari Ada, dimaksudkan Heidegger untuk diuraikan pada divisi ke-3 dari bagian ke-2 dari SZ. Namun divisi ini tidak pernah ditulis dan dielaborasi olehnya. Bdk. W. Large, Heidegger's Being and Time (Edinburgh: Edinburgh University Press, 2008), p. 124.

43 Heidegger, SZ, S. 26.

44 Bdk. Gorner, Heidegger's Being And Time: An Introduction, p. 154.

45 Untuk uraian tentang konsep waktu dari Heidegger, saya mengikuti pemaparan dari F. Budi Hardiman dalam bukunya. Hardiman, Heidegger dan Mistik Keseharian: Suatu Pengantar Menuju Sein und Zeit, hlm. 102-103.

46 Heidegger, SZ, S. 557. 
bukanlah waktu yang primordial dan bukan otentik.

Ketiga, waktu Dasein (Zeitlichkeit) sebagai waktu yang otentik. Kata zeitlich dalam bahasa Jerman berarti "sementara," berkaitan dengan waktu atau temporal. Dasein itu Zeitlich, yaitu mewaktu dan aktif "di dalam waktu" sehingga ia "menciptakan" waktu. ${ }^{47}$ Ia tidak seperti mengadamengada lain yang pasif ada "di dalam" titik-titik waktu-dunia, melainkan Dasein itu aktif "menduniakan" atau "meruangkan" dunia. Bagi Heidegger, Zeitlichkeit terkait erat dengan struktur-struktur Ada manusia sehingga bersifat eksistensial, menyangkut Ada Dasein. Waktu ada di dalam sini dan di luar sana. ${ }^{48}$

Ada dua petunjuk yang mengafirmasi bahwa waktu dari Dasein, Zeitlichkeit, memiliki konsep univok. Pertama, mempertimbangkan karakteristik waktu dari Dasein, Zeitlichkeit, dan; Kedua, pertimbangan Heidegger bahwa waktu dari Dasein, Zeitlichkeit sebagai arti ontologis dari Sorge.

Ada lima karakteristik dari waktu dari Dasein, Zeitlichkeit. Pertama, ekstasis (die Ekstase). "Zeitlichkeit secara primordial 'keluar-dari-dirinya sendiri' dalam dan untuk dirinya sendiri. Oleh karena itu, kita menyebut fenomena masa depan, karakter masa lalu dan masa sekarang (sebagai) 'ekstasis' dari Zeitlichkeit." ${ }^{49}$ Ekstasis dalam bahasa Yunani, ex berarti keluar dan histanai berarti berdiri. Ekstasis dipahami sebagai "berdiri atau melangkah atau keluar dari diri sendiri." ${ }^{50}$ Zeitlichkeit memiliki ciri ekstasis berarti Zeitlichkeit keluar dari dirinya sendiri dan menyatukan tiga dimensinya, yakni, masa lalu (Gewesenheit), masa kini, dan masa depan. Ada kesatuan ekstasis dari Zeitlichkeit. ${ }^{51}$ Zeitlichkeit merentang

47 Watts, The Philosophy of Heidegger, p. 128.

48 Hardiman, Heidegger dan Mistik Keseharian: Suatu Pengantar Menuju Sein und Zeit, hlm. 103-104; Bdk. R. Polt, “Being and Time," in Martin Heidegger: Key Concepts, edited by B. Dawis (Durham, Acumen, 2010), p. 69.

49 "Zeitlichkeit ist das ursprüngliche »Außerß-sich« an und für sich selbst. Wir nennen daher die charakterisierten Phänomene Zukunft, Gewesenheit, Gegenwart die Ekstasen der Zeitlichkeit." Heidegger, SZ, S. 435.

50 Lorens Bagus, "Ekstasis," dalam Kamus Filsafat (Jakarta: Gramedia Pustaka Utama, 1996), hlm. 191.

51 Heidegger, SZ, S. 435; Bdk. M. Inwood, A Heidegger Dictionary (Malden: Blackwell publishers, 1999), p. 221; Bdk. Watts, The Philosophy of Heidegger, p. 122. 
atau melebar pada ketiga dimensi waktu dan menyatukan mereka. Ekstasis Zeitlichkeit dimaknai sebagai pelampauan dari momen-momen atau dimensi-dimensi Zeitlichkeit, suatu gerak eksistensial, seperti juga Dasein adalah eksistensi, dalam pengertian Dasein berdiri di luar dirinya (Ausser-sich). ${ }^{52}$

Kedua, Ekstasis Zeitlichkeit yang terutama adalah masa depan (die Zukunft). "Fenomena pertama dari Zeitlichkeit yang orisinal dan otentik adalah masa depan." ${ }^{53}$ Masa depan adalah kemungkinan. Kemungkinan yang paling otentik adalah kematian. Dasein adalah kemungkinannya sendiri. Dalam kematian, Dasein datang kepada dirinya sendiri. Kematian adalah kemungkinan yang tidak lagi ada atau kemungkinan dari ketidakmungkinan Dasein. Artinya, jika kemungkinkan ini (baca: kematian) diaktualisasikan, maka Dasein berhenti untuk hidup dan ada. Tidak ada satupun yang mempunyai arti untuk Dasein lagi. Tetapi sebaliknya, selama Dasein masih hidup atau ada, kemungkinan kematian selalu ada di depan Dasein, maka Dasein dituntut untuk mengambil keputusan yang otentik. Masa depan tidak dilihat sebagai "masa yang belum teraktualisasi" tetapi bahwa masa depan Zeitlichkeit Dasein ada pada masa sekarang dalam bentuk potensi-potensi atau kemungkinan-kemungkinan dari Dasein untuk memilih, yang pada gilirannya memengaruhi tindakantindakan masa sekarang dari Dasein. ${ }^{54}$

Ketiga, Zeitlichkeit itu terbatas. Masa depan selalu dibatasi oleh kemungkinan akan kematian. Masa depan terbuka kepada kita hanya ketika kita berhadapan dengan kemungkinan-kemungkinan untuk diputuskan..$^{55}$

Keempat, Zeitlichkeit adalah sumber dari konsep waktu objektif sehari-hari dari mengada (Innerzeitigkeit). ${ }^{56}$ Dasein adalah Zeitlich maka ia "menciptakan" waktu. Menurut Heidegger, hanya merujuk pada Zeitli-

52 Inwood, A Heidegger Dictionary, p. 221; Bdk. Hardiman, Heidegger dan Mistik Keseharian: Suatu Pengantar Menuju Sein und Zeit, hlm. 111.

53 "Das primäre Phänomenon der ursprünglichen und eigentlichen Zeitlichkeit ist die Zukunft." Heidegger, SZ, S. 436.

54 Watts, The Philosophy of Heidegger, p. 123.

55 Bdk. Polt, Being and Time, pp. 72-73.

56 Watts, The Philosophy of Heidegger, p. 128. 
chkeit Dasein yang otentik dan orisinal maka sebuah pandangan ontologis tentang waktu menjadi mungkin, sehingga Zeitlichkeit adalah "waktu yang orisinal atau primordial." 57

Kelima, Zeitlichkeit adalah transendental. Ini berarti ada ciri transenden Zeitlichkeit. Transenden merujuk pada keadaan atau kondisi dengan yang mana atau dari yang mana Dasein dapat merefleksikan pada totalitas dari pengalaman manusia. ${ }^{58}$ Merefleksikan totalitas pengalaman manusia menunjukkan bahwa Dasein melampaui dimensi-dimensi atau momenmomen dari Zeitlichkeit, yakni, masa lalu, masa kini dan masa depan. Ciri transenden dari Zeitlichkeit hanya mungkin karena Zeitlichkeit berciri ekstatis. ${ }^{59}$

Dengan merujuk pada karakteristik dari waktu Dasein, Zeitlichkeit yang tersebut sebelumnya, secara khusus pada ciri yang pertama, ekstasis dan kelima, transenden, maka kita dapat melihat ciri univok waktu dari Dasein, Zeitlichkeit. Kedua ciri ini menunjukkan secara tepat bahwa Zeitlichkeit mengambil peran keluar atau melampaui diri mereka dan menyatukan tiga dimensinya, yakni, masa lalu (Gewesenheit), masa kini, dan masa depan. Dengan kata lain, Dasein yang memiliki Zeitlichkeit meyatukan dimensi-dimensi waktu dalam dirinya sendiri. Waktu tidak lagi terpisah-pisah seperti titik-titik garis lurus masa lampau, masa kini dan masa depan. Sebaliknya, waktu adalah Dasein itu sendiri, Dasein adalah Zeitlich. Di dalam Zeitlichkeit, masa lalu, masa kini dan masa depan menjadi satu dan disatukan dalam Dasein.

Demikianlah bagi Heidegger, waktu lampau dari Dasein tidaklah sudah selesai dan sudah berlalu di waktu lampau dan tidak berhubungan dengan masa sekarang. Sebaliknya waktu lampau 'hadir atau hidup' pada masa sekarang karena kondisi-kondisi waktu sekarang yang membutuhkan pertimbangan-pertimbangan waktu lampau. Kemudian mengombinasikan waktu lampau dengan situasi dan tindakan saat sekarang ini guna mengambil keputusan terhadap kemungkinan-

57 Heidegger, SZ, S. 535; Bdk. Watts, The Philosophy of Heidegger, p. 128.

58 Watts, The Philosophy of Heidegger, p. 126.

59 Watts, The Philosophy of Heidegger, p. 127. 
kemungkinan dari masa depan. Jadi mengambil kembali (Wiederholung) masa lalu dan menarik masa depan ke masa kini dengan sikap keterbukaan dalam membuat antisipasi (Vorlaufen) sehingga pada masa sekarang ini dalam momen visi (Augenblick), kita mampu mengambil keputusan atau kebulatan sikap atau tekad dari kemungkinan-kemungkinan yang ada di depan kita. Sebagai misal, ketika Dasein atau kita ingin membuat sebuah keputusan untuk menikah atau tidak menikah, maka pada saat sekarang ini kita mengambil kembali (Wiederholung) masa lalu yakni pengalaman keterlemparan kita (suasana keluarga waktu kecil, relasi ayah dan ibu kita, relasi orang tua dan anak-anak) dan merenungkannya saat sekarang ini dalam kesendirian. Waktu lampau 'hidup atau hadir' pada masa sekarang ini. Lalu pada waktu yang sama, kemungkinan-kemungkinan di masa depan kita antisipasi (Vorlaufen) dalam situasi sekarang ini (apa yang akan terjadi jika kita menikah atau tidak, bagaimana kita menuntun keluarga kita nanti). Kemudian secara simultan, masa sekarang ini dalam momen visi (Augenblick), kita mengambil keputusan atau kebulatan tekad untuk menikah atau tidak menikah. Jadi Zeitlichkeit adalah masa depan yang juga masa kini dan masa lalu karena pada keduanya sudah ada antisipasi kemungkinan di masa depan. "Zeitlichkeit menghasilkan dirinya sebagai masa depan yang sudah ada dan sekaligus hadir (gewesendegegenwärtigende Zukunft)." 60

Demikianlah bagi Heidegger Zeitlichkeit menjadi horizon atau locus dimana dimensi-dimensi waktu masa lalu, masa kini dan masa depan bertemu dan menjadi satu. Ini adalah ciri -ciri dari konsep univok. Dengan memahami bahwa Zeitlichkeit adalah konsep univok karena melampaui dan menyatukan dimensi-dimensi waktu, maka tidak sulit untuk memahami bahwa Ada adalah univok. Mengapa demikian? Karena bagi Heidegger, "Ada menemukan artinya di dalam Zeitlichkeit."61 Ini berarti bahwa Zeitlichkeit sebagai horizon atau locus dari Ada yang menyingkapkan dirinya. Karena Zeitlichkeit, yang adalah horizon atau locus dari Ada, adalah univok maka Ada "hanya bisa dipahami" sebagai univok. Ini menunjukkan bahwa Ada itu univok dalam Heidegger. "Time

60 Heidegger, SZ, S. 350.

61 Heidegger, SZ, S. 27. 
is a univocal concept for Heidegger and being, since it is understood in terms of time, is understood univocally." 62

Konsep waktu dari Dasein, Zeitlichkeit adalah univok dipahami pula dengan mempertimbangkan waktu dari Dasein, Zeitlichkeit sebagai arti ontologis dari Sorge. ${ }^{63}$ Bagi Heidegger, Ada Dasein adalah Sorge dan Sorge adalah struktur total dan seluruh eksistensi dari Dasein. ${ }^{64}$ Arti dari Sorge adalah waktu dari Dasein, Zeitlichkeit. "Zeitlichkeit mewahyukan dirinya sendiri sebagai arti dari Sorge yang otentik." 65

Heidegger merumuskan secara tepat pengertian Sorge sebagai, "Sich-vorweg-schon-sein-in-(der Welt-) as Sein-bei (innerweltlich begegnendem Seienden)." 66 Dari definisi ini, Sorge menunjukkan tiga struktur utama dari Ada Dasein, yakni: pertama, proyeksi diri kepada kemungkinan di masa depan atau mendahului (Sich vorweg) atau ada-di-depan-dari-diri sendiri (Entwurf), dan inilah eksistensialitas Dasein; ${ }^{67}$ Kedua, keterlemparan atau sudah-ada-di-dalam-dunia (Schon-sein-in-der-Welt), dan inilah faktisitas Dasein, ${ }^{68}$ dan; Ketiga, ada bersama mengada-mengada yang lain atau bermukim pada entitias yang dijumpai di dunia ini (Sein bei innerweltlich begegnendem Seienden), dan inilah kejatuhan Dasein. ${ }^{69}$ Heidegger mempertimbangkan bahwa ketiga struktur atau dimensi utama dari Ada Dasein tersebut memiliki kesatuan secara esensial: "Sorge adalah keseluruhan Ada

62 P. Tonner. Heidegger, Metaphysics and in the Philosophy of Being (London: Continuum, 2010), p. 116.

63 Catatan yang diberikan oleh F. Budi Hardiman sangat membantu untuk memahami arti dari Sorge. Kata Sorge dalam bahasa Jerman berarti kekhawatiran, perhatian, kepeduliaan, maupun pemeliharaan. Diterjemahkan dalam bahasa Inggris dengan care. Menimbang banyaknya muatan arti dari kata ini dan tak tergantikan dengan bahasa Indonesia, maka mengikuti catatan F. Budi Hardiman, istilah Sorge digunakan dalam makalah ini dan tidak diterjemahkan dengan kata Indonesia. Lih. Hardiman, Heidegger dan Mistik Keseharian: Suatu Pengantar Menuju Sein und Zeit, hlm. 84.

64 Untuk uraian tentang konsep Sorge dari Heidegger, penulis mengikuti pemaparan dari F. Budi Hardiman dalam bukunya Heidegger dan Mistik Keseharian. Hardiman, Heidegger dan Mistik Keseharian: Suatu Pengantar Menuju Sein und Zeit, hlm. 84-94.

65 Heidegger, SZ, S. 432.

66 Heidegger, SZ, S. 256; Lih. Hardiman, Heidegger dan Mistik Keseharian: Suatu Pengantar Menuju Sein und Zeit, hlm. 85-86.

67 Bdk. Tonner, Heidegger, Metaphysics and the Univocity of Being, p. 112.

68 Bdk. Gorner, Heidegger's Being And Time: An Introduction, p. 10.

69 Bdk. Hardiman, Heidegger dan Mistik Keseharian: Suatu Pengantar Menuju Sein und Zeit, hlm. 85-86; Bdk. Watts, The Philosophy of Heidegger, pp. 120-121. 
Dasein yang serentak memuat ketiganya, yakni mengantisipasi masa depan (eksistensialitas), terlempar di dunia (faktisitas), dan larut dalam keseharian (kejatuhan). Serentak? Ya, karena dalam Sorge keterlemparan, antisipasi, dan kelarutan utuh menjadi satu dalam satu sikap yang paling mendasar sebagai manusia." 70

Demikianlah bahwa Sorge Dasein membuat mungkin kesatuan antara masa depan-eksistensialitas, masa lampau-faktisitas, dan masa sekarangkejatuhan sehingga mereka menjadi satu di dalam Zeitlichkeit. ${ }^{71}$ Keserentakan dan kesatuan adalah ciri mendasar dari konsep univok dari Duns Scotus dan ditemukan dalam Zeitlichkeit.

Setelah memahami bahwa konsep waktu dari Dasein, Zeitlichkeit adalah univok, kita mampu memahami sekarang bahwa Ada adalah univok dalam pemikiran Heidegger. Sebagaimana dinyatakan pada awal tulisan bahwa Ada itu univok terjadi pada konsep waktu Dasein, Zeitlichkeit. Interpretasi Ada sebagai waktu dimaksudkan untuk menunjukkan bahwa analogia entis tidak mungkin. ${ }^{72}$ Dengan kata lain, dasar dari sebuah konsep Ada yang univok berkenaan dengan waktu ${ }^{73}$ dan konsep Ada itu univok berakar secara khusus pada waktu dari Dasein, Zeitlichkeit. ${ }^{74}$

Ada adalah penyingkapan diri sebagai sebuah kehadiran yang penuh arti kepada Dasein, kita manusia. Bagi Heidegger, Dasein adalah locus dari penyingkapan atau pewahyuan Ada. Dasein adalah mengada yang menyadari keterlemparannya di dunia dan mampu bertanya untuk memahami keterlemparan itu serta memiliki relasi dengan Ada. ${ }^{75}$ Oleh karena itulah, Dasein selalu membuka diri kepada Ada.

Ada sebagai penyingkapan diri kepada Dasein berarti Ada sebagai peristiwa kemewaktuan menyingkapkan kehadirannya yang penuh arti

70 Hardiman, Heidegger dan Mistik Keseharian: Suatu Pengantar Menuju Sein und Zeit, hlm. 85. Penekanan dibuat oleh penulis untuk menunjukkan ciri univok dari Sorge.

71 Heidegger, SZ, S. 434 und 495.

72 Lih. S.J. McGrath, The Early Heidegger and Medieval Philosophy, Phenomenology for the Godforsaken (Washington, D.C.: The Catholic University of America Press, 2006), p. 20.

73 Tonner, Heidegger, Metaphysics and the Univocity of Being, p. 33.

74 Tonner, Heidegger, Metaphysics and the Univocity of Being, p. 21.

75 "Dieses Seiende, das wir selbst je sind und das unter anderem die Seinsmöglichkeit des Fragens hat, fassen wir terminologisch als Dasein." Heidegger, SZ, S. 10. 
dalam waktu dari Dasein, Zeitlichkeit. Konsekuensinya, karena penyingkapan Ada adalah peristiwa kemewaktuan, bahwa Dasein adalah waktu itu sendiri, dan penyingkapan Ada terjadi dalam Zeitlichkeit yang berciri univok, maka Ada itu univok. ${ }^{76}$ Konsep Zeitlichkeit yang univok merupakan horizon atau locus yang menyatukan beraneka cara Ada menyingkapkan atau mewahyukan diri. Dalam Zeitlichkeit semua perbedaan cara Ada menyingkapkan diri disatukan.

\section{PENUTUP}

Dari pemaparan sebelumnya, tampak kehadiran konsep Ada itu univok dari Duns Scotus dalam pemikiran Heidegger khususnya dalam magnum opus-nya, Sein und Zeit. Afirmasi ini didasarkan pada konsep waktu dari Dasein, (Zeitlichkeit). Kendati konsep Ada itu univok menurut Duns Scotus tidak tampak secara eksplisit dalam karya-karya Heidegger namun secara implisit konsep Ada dari Heidegger tetap tinggal univok. Konsep Ada itu univok inilah yang menyatukan filsafat Duns Scotus dan Heidegger.

Perbedaan diantara mereka adalah bahwa Ada itu univok dalam pemikiran Duns Scotus terletak pada konsep ada itu sendiri (Sein an sich) dengan konteks upaya memahami atribut-tribut Allah, sedangkan Ada itu univok dalam pemikiran Heidegger terletak pada konsep waktu Dasein (Zeitlichkeit). Konsep waktu Dasein adalah univok, sehingga Ada itu univok, sebab penyingkapan Ada (Sein as sich) dalam bentuk apapun hanya terjadi dalam Zeitlichkeit. Jadi dalam filsafat Heidegger Ada itu univok ada dalam istilah waktu Dasein, Zeitlichkeit dan kesatuan Ada (baca: Ada itu univok) berakar dalam konsep waktu Dasein, Zeitlichkeit.

\section{DAFTAR RUJUKAN}

Aristotle. "Categories." In The Complete Works of Aristotle, vol. I, translated by J.L. Ackrill and edited by J. Barnes. Princeton, N.J.: Princeton University Press, 1991.

76 Tonner, Heidegger, Metaphysics and the Univocity of Being, p. 172; Martin Heidegger, The Concept of Time, translated by William McNeil (Malden: Blackwell Publishing, 1992), pp. 13E-14E. 

tle, vol. II, translated by W. D. Ross and edited by J. Barnes. Princeton, N.J.: Princeton University Press, 1991.

"Metaphysics." In The Complete Works of Aristotle, vol. II, translated by W. D. Ross, edited by J. Barnes. Princeton, N.J.: Princeton University Press, 1991.

. "Prior Analytics." In The Complete Works of Aristotle, vol. I, translated by A. J. Jenkinson and edited by J. Barnes. Princeton, N.J.: Princeton University Press, 1991.

"Poetics." In The Complete Works of Aristotle, vol. II, translated by I. Bywater and edited by J. Barnes. Princeton, N.J.: Princeton University Press, 1991.

"Rhetoric." In The Complete Works of Aristotle, vol. II, translated by W. Rhys Roberts and edited by J. Barnes. Princeton, N.J.: Princeton University Press, 1991.

Bagus, Lorens. Kamus Filsafat. Jakarta: Gramedia Pustakan Utama, 1996.

Berti, E. "L'analogia dell'essere nella tradizione aristotelico-tomistica." In Metafore dell'invisibile: ricerche sull'analogia, contribute al XXXIII Convegno del Centro di Studi filosofici di Gallarate - Aprile 1983. Brescia: editrice Morcelliana, 1984.

"L'analogia in Aristotele interpretazioni recenti e possibili sviluppi." In Origini e sviluppi dell'analogia: da Parmenide a San Tommaso, a cura di G. Cassetta. Roma: Edizioni Vallombrosa, 1987.

Deleuze, Gilles. Difference and Repetition, translated by P. Patton. New York: Columbia University Press, 1994.

De Aquino, Thomae. "Summae Theologie, vol. IV." In Opera Omnia. Romae: editio Leonina, 1888.

editio Leonina, 1889.

"Summae Theologie vol. V." In Opera Omnia. Romae:

."Summa Theologica vol. I." In Complete English Edition in Five Volumes, translated by Fathers of the English Dominican Province, Indiana: Ave Maria Press, Notre Dame, 1948.

Duns Scotus, Iohannes. Opera Philosophica I-V, edited by G. J. Etzkorn et all. St. Bonaventure, N.Y. Washington D.C.: The Catholic University of America Press, 1999-2006.

"Ordinatio I-IV." In Opera Omnia I-XIV, a cura di Commissionis Scotisticae. Civitas Vaticana: Typis Polyglottis 
Vaticanis, 1950-2013.

. "Man's Natural Knowledge of God." In Duns Scotus Philosophical Writings, translated by A. Wolter and edited by R. Klibansky. Indianapolis: Hackett Publishing Company, 1987.

Dumont, S. "The Univocity of the Concept of Being in the Fourteenth Century: John Duns Scotus and William of Alnwick." in Mediaeval Studies 49 (1). Toronto: Pontifical Institute of Mediaeval Studies, 1987.

. "Henry of Ghent and Duns Scotus." In Routledge History of Philosophy, vol. III, edited by J. Marenbon. London: Routlegde, 1998.

Gracia, J. "Philosophy in the Middle Ages: An Introduction." In A Companion to Philosophy in the Middle Ages, edited by J. Gracia and T. B. Noone. Oxford: Blackwell Publishing, 2006.

Gorner, P. Heidegger's Being And Time: An Introduction. Cambridge: Cambridge Unversity Press, 2007.

Hardiman, F. Budi. Heidegger dan Mistik Keseharian: Suatu Pengantar Menuju Sein und Zeit. Jakarta: Kepustakaan Populer Gramedia, 2003.

Heidegger, M. Sein und Zeit, Gesamtausgabe Band 2. Frankfurt am Main: Vittorio Klostermann, 1977.

. Being and Time, translated by J. Macquarrie \& E. Robinson. Malden: Blackwell Publishing, 1962.

. The Concept of Time, translated by William McNeil. Malden: Blackwell Publishing, 1992.

Inwood, M. A Heidegger Dictionary. Malden: Blackwell publishers, 1999.

King, P. "Scotus on Metaphysics." In The Cambridge Companion to Duns Scotus, edited by T. Williams. Cambridge: Cambridge University Press, 2003.

Large, W. Heidegger's Being and Time. Edinburgh: Edinburgh University Press, 2008.

McGrath. S.J., The Early Heidegger and Medieval Philosophy, Phenomenology for the Godforsaken. Washington, D.C.: The Catholic University of America, 2006.

Montagnes, B. The Doctrine of the Analogy of Being According to Thomas Aquinas, translated by E. M. Macierowski and edited by A. Tallon. Milwaukee: Marquette University Press, 2004.

Online Etymology Dictionary. http:/ / www.etymonline.com/index. php?allowed_in_frame=0\&search=equivocal. Diakses pada 17 
Agustus 2017.

Online Etymology Dictionary.

http://www.etymonline.com/index.php?allowed_in_frame=0\&search=univok. Diakses pada 17 Agustus 2017.

Online Etymology Dictionary. http://www.etymonline.com/index. php?allowed_in_frame $=0 \&$ search=analogy. Diakses pada 17 Agustus 2017.

Polt, R. “Being and Time." In Martin Heidegger: Key Concepts, edited by B. Dawis. Durham: Acumen, 2010.

Shields, C. Order in Multiplicity, Homonymy in the Philosophy of Aristotle. Oxford: Oxford University Press, 1999.

Tonner, P. Heidegger, Meraphysics and in the Philosophy of Being. London: Continuum, 2010.

Watts, M. The Philosophy of Heidegger. Durham: Acumen Publishing Limited, 2011. 